\title{
HUBUNGAN PERILAKU CARING PERAWAT TERHADAP TINGKAT KECEMASAN PASIEN PRE OPERATIF DI RUANG RAWAT INAP BEDAH PRIA DAN WANITA RSUP DR. M. DJAMIL PADANG
}

\author{
Yuanita Ananda ${ }^{1}$, Asmawati ${ }^{2}$ \\ ${ }^{1}$ STIKes Alifah Padang \\ Email: Yuanita_ananda88@yahoo.com
}

\begin{abstract}
ABSTRAK
Kecemasan mulai dirasakan klien saat pertama kali dinyatakan dokter bahwa penyakitnya memerlukan tindakan pembedahan. Kecemasan pasien dapat diatasi salah satunya dengan perilaku caring perawat. Kurangnya perawat memberikan penjelasan dan kurang melakukan pendekatan dengan pasien sehingga pasien merasa cemas. Tujuan penelitian ini adalah untuk mengetahui hubungan perilaku caring perawat terhadap tingkat kecemasan pasien pre operatif

Jenis penelitian analitik dengan desain cross sectional. Populasi dalam penelitian ini adalah pasien pre operatif yang berada di Ruang Rawat Inap Bedah RSUP Dr. M. Djamil Padang dengan sampel 96 orang dengan sampel 50 orang menggunakan teknik accidental sampling. Data dianalisa secara univariat tabel distribusi frekuensi dan bivariat dengan uji statistik Chi-Square.

Hasil penelitian menunjukkan bahwa kurang dari separoh $(44,8 \%)$ perawat memiliki perilaku caring kurang baik. Lebih dari separoh $(52,1 \%)$ memiliki kecemasan berat. Ada hubungan perilaku caring dengan kecemasan pasien pre operatif di Ruang Rawat Bedah dan Wanita RSUP Dr. M. Djamil Padang uji statistik diperoleh $p$ value $=$ $0,000(\mathrm{p} \leq 0,05)$.

Kesimpulan peneliti ada hubungan perilaku caring dengan kecemasan pasien pre operatif. Diharapkan melalui Pimpinan RSUP Dr. M. Djamil Padang untuk dapat mempertahankan kinerja yang ada dalam melakukan caring oleh perawat sehingga pasien merasa nyaman.
\end{abstract}

\section{Kata Kunci : Perilaku Caring dan Tingkat Kecemasan}

\section{ABSTRACT}

Patient anxiety can be overcome either by the nurse caring behaviors. Caring is an attitude of caring respect and appreciate the preferences of a thinking, acting and feeling. Lack of nurses provide explanations and less approach with the patient so that patients feel anxious. The purpose of this study was to determine the relationship of nurses caring behavior towards patients preoperative anxiety levels.

Type of the research is analytical descriptive with cross-sectional approach. The population in this study is that patients who are in the pre -operative in Space Inpatient Surgical Hospital Dr. M. Djamil Padang with a sample of 96 people with 50 respondens. The sampling technique is accidental sampling. Data were analyzed using univariate and bivariate frequency distribution table using statistical test Chi - Square.

The results showed that less than half $(44,8 \%)$ nurses have less good caring behavior. More than half $(52,1 \%)$ have anxiety. There is a relationship with a caring behavior preoperative patient anxiety in Patients Pre Operative Surgery at The Hospital of Dr. M. Djamil of Padang $p$ value = 0,000.

The researchers' conclusion is no relationship caring behavior with pre-operative patient anxiety. Leaders are expected through the Hospital Dr. M. Djamil Padang to maintain existing performance in doing the caring nurses so that patients feel comfortable.

Keyword : Caring Behavior and Anxiety Level 


\section{Pendahuluan}

Pelayanan kesehatan yang bermutu merupakan salah satu tolak ukur kepuasan yang berefek terhadap keinginan pasien untuk kembali kepada institusi yang memberikan pelayanan kesehatan yang efektif. Bentuk pelayanan yang efektif antara pasien dan pemberi pelayanan (provider) di sadari sering terjadi perbedaan persepsi (Handayani, 2012).

Pembedahan atau operasi merupakan salah satu dari pelayanan kesehatan yang ada di rumah sakit. Pembedahan atau operasi adalah semua tindakan pengobatan yang menggunakan cara invasif dengan membuka atau menampilkan bagian tubuh yang akan ditangani. (Sjamsuhidayat, 2011).

Tindakan pembedahan merupakan pengalaman yang bisa menimbulkan kecemasan, kecemasan merupakan masalah yang sering muncul di pusat pelayanan kesehatan atau rumah sakit. Kecemasan pasien pre operatif dapat dilihat dengan tanda dan gejala meningkatnya frekuensi nadi, pernafasan, gerakan-gerakan tangan yang tidak terkontrol, telapak tangan yamg lembab, gelisah, menanyakan pertanyaan yang sama berulang kali, sulit tidur, sering berkemih (Carpenito, 2002).

Menurut Hawari (2011) diperkirakan jumlah orang yang menderita gangguan kecemasan baik akut maupun kronik mencapai 5\% dari jumlah penduduk, dan di perkirakan antara $2 \%$ - $4 \%$ diantara penduduk disuatu saat dalam kehidupannya pernah mengalami gangguan cemas. Menurut Carpenito (2002) menyatakan bahwa $90 \%$ pasien pre operatif berpotensi mengalami kecemasan.

Kecemasan yang dialami pasien pre operatif mempunyai bermacam-macam alasan diantaranya cemas menghadapi ruang operasi dan peralatan operasi, cemas terjadinya perubahan fisik (body image) yang berupa cacat anggota tubuh, cemas dan takut di bius, cemas bila operasi gagal, ataupun cemas masalah biaya yang membengkak (Sawitri, 2008).

Menurut Caplan (2010) kecemasan pasien pre operatif dipengaruhi oleh beberapa faktor diantaranya yaitu usia, jenis kelamin, pengalaman pasien menjalani operasi, konsep diri dan peran, tingkat pendidikan, tingkat sosial ekonomi, kondisi medis, akses informasi, proses adaptasi, jenis tindakan medis dan komunikasi terapeutik yang diiringi dengan perilaku caring perawat terhadap pasien.

Perawat merupakan tenaga kesehatan yang profesional selama 24 jam menjalin kontak dengan pasien yang mempunyai kesempatan untuk memberi pelayanan kesehatan berupa asuhan keperawatan yang komprehensif dengan membantu klien dalam memenuhi kebutuhan dasar yang holistik bersifat caring. Sebab caring merupakan bagian terpenting dalam asuhan keperawatan yang menyangkut hubungan perawat dan klien dalam memberi dukungan psikologis serta emosional kepada klien dan keluarga, baik secara verbal dan non verbal dalam proses pelayanan keperawatan sehingga dapat meningkatkan rasa aman dan keselamatan klien (Rasyid, 2013).

Caring adalah suatu sikap rasa peduli hormat dan menghargai kesukaan-kesukaan seorang berfikir, bertindak dan berperasaan. (Dwidiyanti, 2007).

Penelitian Salbiah (2014) tentang hubungan perilaku caring dengan harapan pasien dalam kepuasan perilaku caring perawat di RSUD Deli Serdang Lubuk Pakam ditemukan hasil 94,3\% pasien memiliki harapan yang tinggi. $78,6 \%$ pasien merasa puas terhadap perilaku caring perawat. Ada hubungan perilaku caring dengan kepuasan pasien.

Penelitian Hidayati (2013) tentang hubungan perilaku caring perawat dengan tingkat kecemasan pasien rawat Inap di Rumah Sakit PKU Muhammadiyah Surakarta ditemukan hasil caring kurang (17\%) dan kecemasan ringan (42\%) dan ada hubungan perilaku caring dengan kecemasan pasien perawat ( $\mathrm{p}$ value $=0,000$ )

RSUP Dr. M. Djamil Padang merupakan salah satu rumah sakit terbesar di Sumatera Barat dengan status rumah sakit tipe A dan rumah sakit pendidikan, serta sebagai pusat rujukan untuk wilayah Sumatera Bagian Tengah. Rumah Sakit ini juga merupakan salah satu rumah sakit di Profinsi Sumatera Barat yang menerapkan program patient safety rumah sakit. Serta visi rumah sakit ini adalah menjadi "Rumah Sakit yang terunggul dalam pelayanan dan pendidikan di Sumatera Barat”. (Profil RSUP Dr. M. Djamil Padang, 2015).

Berdasarkan studi pendahuluan yang dilakukan oleh peneliti di RSUP Dr. M. Djamil didapatkan laporan data rekam medik IRNA Bedah di RSUP Dr. M. Djamil Padang, pasien yang telah dilakukan tindakan operasi pada tahun 2015 sebanyak 6.611 pasien. Sementara pada bulan Mei 2016 sebanyak 149 orang. Dari 8 pasien yang akan dilakukan tindakan operasi dengan diagnosa medis yang berbeda-beda, memiliki respon kecemasan. Kecemasan mulai dirasakan klien saat pertama kali dinyatakan dokter bahwa penyakitnya memerlukan tindakan pembedahan guna penyembuhan sampai klien akan dilakukan tindakan pembedahan, 5 pasien yang mengatakan merasa cemas dari biasanya, takut akan operasi dapat menyebabkan meninggal, 2 pasien mengatakan sering merasakan jantung berdebar-debar, mengalami mimpi buruk. Hal ini dikarenakan perawat memberikan penjelasan kurang jelas dan perawat kurang melakukan pendekatan dengan pasien sehingga pasien merasa cemas dan 3 pasien mengatakan sulit tidur, sering terbangun tengah malam, merasa gugup, tidak dapat menahan BAK, hal ini terus klien rasa sebelum tindakan pembedahan. 
Kondisi tersebut tentunya mendapatkan perhatian yang cukup serius dari semua pihak yang terkait. Oleh karena itu peneliti berupaya untuk menggali tentang hal tersebut dan berdasarkan observasi peneliti di RSUP. Dr. M. Djamil Padang terhadap beberapa perawat yang bertugas disana, didapatkan selama ini yang dilakukan oleh perawat cenderung pada penanganan penyakit fisik pasien saja seperti pemasangan infus dari pada aspek psikologis pasien seperti menjelaskan pada pasien bahwa operasinya dilakukan oleh seorang dokter spesialis dan perawat memberi informasi bahwa operasi yang akan dilaksanakan hanya sebentar.

Berdasarkan hal yang dilakukan peneliti diruang rawat didapatkan kecenderungan perawat tidak memperkenalkan dirinya ketika pertama kali kontak dengan klien, sehingga hubungan saling percaya tidak terbina dengan baik, tidak menanyakan bagaimana perasaan klien, jarang menjelaskan prosedur dan tindakan yang akan dilakukan (seperti saat pengukuran tanda-tanda vital, saat pemasangan infus serta pada saat pemasangan kateter). Hal seperti ini tentu bisa menimbulkan respon kecemasan pada klien, dan beberapa perawat terlihat sibuk dengan pekerjaan sendiri. Hal ini tentu memberikan dampak yang berkaitan dengan keadaan pasien.

\section{METODE PENELITIAN}

Penelitian ini telah dilakukan pada bulan Oktober sampai Desember 2017 di RSUP Dr.M.Djamil Padang. Jenis penelitian ini adalah analitik untuk melihat kejadian yang diteliti dengan desain penelitian yang digunakan adalah cross sectional. Populasi dalam penelitian ini adalah pasien pre operatif yang berada di Ruang Rawat Inap Bedah RSUP Dr. M. Djamil Padang. Sampel penelitian yaitu sebanyak 96 orang responden dengan teknik pengambilan accidental sampling. Teknik pengumpulan data yang dipergunakan dalam penelitian ini yaitu pengumpulan data primer dengan melakukan pengukuran tingkat kecemasan secara langsung kepada pasien pre operatif. Penelitian ini menggunakan analisis Univariat dan analisis bivariat dengan uji statistik chi square dengan tingkat kepercayaan (confidence interval) $95 \%$ atau $\alpha 0,05$.

\section{HASIL}

Tabel 1.2

Distribusi Frekuensi Responden Berdasarkan Tingkat kecemasan pasien post operasi di RSUP Dr. M. Djamil Padang

\begin{tabular}{|c|c|c|}
\hline Kecemasan & $\boldsymbol{F}$ & $\%$ \\
\hline Berat & 50 & 52,1 \\
\hline Ringan & 46 & 47,9 \\
\hline Jumlah & 96 & 100 \\
\hline
\end{tabular}

Berdasarkan tabel 2.1 di dapatkan dari 96 responden didapatkam lebih dari separoh (52.1\%) tingkat kecemasan pasien post operasi berat

Tabel 2.2

Distribusi Frekuensi Responden Berdasarkan Perilaku Caring perawat di RSUP Dr. M. Djamil Padang

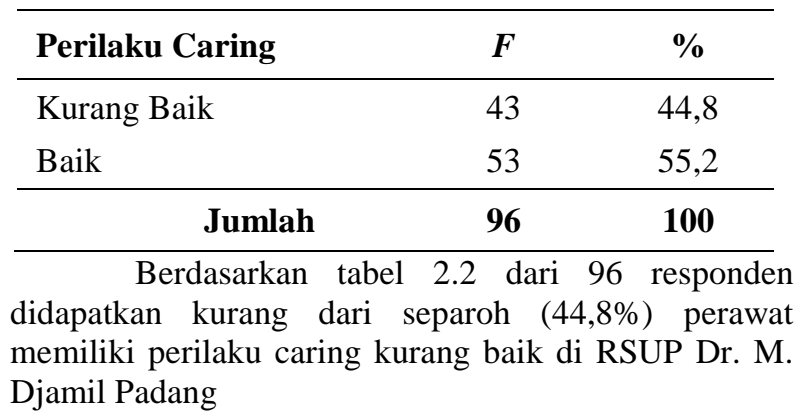

Tabel 2.3

Hubungan Caring dengan tingkat kecemasan pasien post operasi di RSUP Dr. M. Djamil Padang

\begin{tabular}{|c|c|c|c|c|c|c|c|}
\hline \multirow[t]{3}{*}{ Motivasi } & \multicolumn{4}{|c|}{ Kepatuhan } & \multirow{2}{*}{\multicolumn{2}{|c|}{ Jumlah }} & \multirow{3}{*}{$\begin{array}{l}\mathbf{P} \\
\text { value }\end{array}$} \\
\hline & \multicolumn{2}{|c|}{ Patuh } & \multicolumn{2}{|c|}{$\begin{array}{l}\text { Tidak } \\
\text { Patuh }\end{array}$} & & & \\
\hline & f & $\%$ & $\mathbf{F}$ & $\%$ & f & $\%$ & \\
\hline $\begin{array}{l}\text { Kurang } \\
\text { Baik }\end{array}$ & 35 & 81,4 & 8 & 18,6 & 43 & 100 & 0.000 \\
\hline Baik & 15 & 28,3 & 38 & 71,7 & 53 & 100 & \\
\hline Jumlah & 50 & 52,1 & 46 & 47,9 & 96 & 100 & \\
\hline
\end{tabular}

kecemasan berat lebih banyak pada perilaku caring perawat kurang baik $(81,4 \%)$ dibandingkan dengan kecemasan ringan $(18,6 \%)$. Berdasarkan hasil uji statistik diperoleh $p$ value $=0,000$ terdapat hubungan perilaku caring dengan kecemasan pasien pre operatif di Ruang Rawat Inap Bedah Pria dan Wanita RSUP Dr. M. Djamil Padang. 


\section{PEMBAHASAN}

Hasil penelitian ini hampir sama dengan penelitian yang dilakukan oleh Hidayati (2013) tentang hubungan perilaku caring perawat dengan tingkat kecemasan pasien rawat Inap di Rumah Sakit PKU Muhammadiyah Surakarta ditemukan hasil caring kurang (17\%). Caring adalah kekuatan pendorong utama yang memotivasi seseorang untuk masuk ke dalam profesi keperawatan. Caring juga dapat diartikan memberikan bantuan kepada individu, atau sebagai advikat pada individu yang tidak mampu memenuhi kebutuhan dasarnya (Nursalam, 2011).

Asumsi peneliti perilaku caring perawat yang kurang baik pada penelitian ini dikarenakan pemahaman perawat dalam menilai atau memahami kemampuan pengetahuan atau emosi pasien, kurangnya perawat memberikan penjelasan karena kesibukan dalam mengurus pasien, selain itu ditemukan juga perawat dalam memberikan pelayanan keperawatan tidak sesuai dengan kebutuhan pasien.

Hasil penelitian ini hampir sama dengan penelitian yang dilakukan oleh Hidayati (2013) tentang hubungan perilaku caring perawat dengan tingkat kecemasan pasien rawat Inap di Rumah Sakit PKU Muhammadiyah Surakarta ditemukan hasil pasien mengalami kecemasan ringan $(40,2 \%)$.

Kecemasan adalah suatu keadaan dimana individu atau kelompok mengalami perasaan yang sulit (ketakutan) dan aktifasi sistem syaraf otonom dalam berespon terhadap ketidak jelasan ancaman yang tidak spesifik (Hawari, 2011). Kecamasan adalah kekuatiran yang tidak jelas dan menyebar, yang berkaitan dengan perasan tidak pasti dan tidak berdaya. Keadaan dialami secara subjektif dan dikomunikasikan secara interpersonal. Kecemasan adalah respon emosional terhadap penilaian yang menggambarkan keadaan khawatir, gelisah, takut, tidak tentram disertai berbagai keluhan fisik. Keadaan tersebut dapat terjadi dalam berbagai situasi kehidupan maupun gangguan sakit (Stuart, 2007).

Asumsi peneliti kecemasan berat pada pasien dalam menghadapi tindakan operasi pada penyakitnya ini dikarenakan responden tidak terbiasa untuk rawat inap di rumah sakit atau menghadapi tindakan operasi tersebut. Hal ini dapat dilihat bahwa ditandai dengan gejala ketegangan berat sekali, sering mengalami gejala gangguan tidur, sering mengalami gangguan kecerdasan, mengalami perasaan depresi atau murung, mengalami gejala penafasan, mengalami gejala pencernaan dan kecemasan terlihat pada tingkah laku atau sikap saat wawancara.

Hasil penelitian ini sama dengan penelitian yang dilakukan oleh Hidayati (2013) tentang hubungan perilaku caring perawat dengan tingkat kecemasan pasien rawat Inap di Rumah Sakit PKU Muhammadiyah Surakarta ditemukan hasil ada hubungan perilaku caring dengan kecemasan pasien perawat ( $p$ value $=0,000$ ).

Rasa cemas atau ancietas dapat dimiliki oleh setiap pasien maupun keluarga pasien yang sedang berada di rumah sakit, rasa cemas ini berbeda-beda antara setiap orang. Rasa cemas tidak mendapatkan perhatian didalam suatu lingkungan, maka rasa cemas itu dapat menimbulkan suatu masalah yang serius (Potter, 2005). Kecemasan menjadi sebuah yang serius sering sekali muncul di pusat pelayanan kesehatan atau rumah sakit. Diperkirakan jumlah orang yang menderita gangguan kecemasan baik akut maupun kronik dan diperkirakan disuatu saat dalam kehidupannya pernah mangalami gangguan cemas (Hawari, 2011).

Caring adalah suatu sikap rasa peduli hormat dan menghargai kesukaan-kesukaan seorang berfikir, bertindak dan berperasaan. Caring suatu tindakan yang digambarkan sebagai suatu emosi, perasan belas kasih atau empaty terhadap pasien yang mendorong perawat untuk memberikan asuhan keperawatan bagi pasien. Perasaan tersebut harus ada dalam diri perawat supaya mereka bisa merawat pasien (Dwidiyanti, 2007).

Asumsi peneliti, penelitian ini menunjukkan bahwa terdapat hubungan antara perilaku caring perawat dengan tingkat kecemasan pasien, dimana semakin baik caring perawat maka tingkat kecemasan pasien semakin turun. Kecemasan timbul pada pasien di karenakan masih ada pasien yang memiliki pendidikan rendah. Pendidikan yang rendah ini tidak dapat mengaplikasikan apa yang disampaikan oleh perawat, oleh karena itu pasien merasa cemas karena tidak mengetahui tentang keadaannya sekarang ini.

\section{KESIMPULAN}

Prilaku caring perawat yang kurang baik dapat meningkatkan kecemasan pada pasien post operasi sehingga hubungan perilaku caring dengan kecemasan pasien pre operatif di Ruang Rawat Inap Bedah Pria dan Wanita RSUP Dr. M. Djamil Padang uji statistik diperoleh $p$ value $=0,000(\mathrm{p} \leq 0,05)$. Dapat disarankan melalui Pimpinan RSUP Dr. M. Djamil Padang untuk dapat mempertahankan kinerja yang ada dalam melakukan caring oleh perawat sehingga pasien merasa nyaman 


\section{DAFTAR PUSTAKA}

1. Caplan, 2010. Sinopsis Psikiatri. Jakarta : EGC

2. Carpenito, 2002. Buku Saku Diagnosa Keperawatan. Edisi 8. Jakarta: EGC.

3. Dwidiyanti, M. (2007). Caring. Semarang : Hapsari

4. Handayani, 2012. Buku Ajar Pelayanan Keluarga Berencana, Yogyakarta: Pustaka Rihama

5. Hawari, 2011. Manajemen Stres Cemas dan Depresi, Jakarta : FKUI

6. Hidayat, 2010. Metode Penelitian Keperawatan dan Teknik Analisis Data. Jakarta : Salemba Medika.

7. Hidayati, 2013. Hubungan Perilaku Caring Perawat Dengan Tingkat Kecemasan Pasien Rawat Inap di Rumah Sakit PKU Muhammadiyah Surakarta, Jurnal Skripsi

8. Morrison, 2009. Caring dan Comunnicating : Hubungan Interpersonal Dalam Keperawatan, Edisi, Jakarta : EGC

9. Notoatmodjo, 2010. Metodologi Penelitian, Jakarta : Rineka Cipta

10. Nursalam, 2011. Manajemen Keperawatan, Aplikasi Dalam Praktik Keperawatan Profesional, Edisi 3, Jakarta : Salemba Medika.

11. Oswari, 2005. Bedah dan Keperawatannya. Jakarta : PT Gramedia.

12. Savitri, 2008. Kecemasan.Jakarta. Pustaka Popular Obor.

13. Sjamsuhidayat, 2011. Buku Ajar Ilmu Bedah. Jakarta:EGC

14. Stuart, 2007. Buku Saku Keperawatan Jiwa, Jakarta : EGC

15. Wulan \& Hastuti, M. 2011. Pengantar Etika Keperawatan. Jakarta: Prestasi Pustaka. 
